\title{
Protein BEX3
}

National Cancer Institute

\section{Source}

National Cancer Institute. Protein BEX3. NCI Thesaurus. Code C28561.

Protein BEX3 (111 aa, $\sim 13 \mathrm{kDa}$ ) is encoded by the human BEX3 gene. This protein plays a role in the regulation of nerve growth factor-dependent apoptosis. 